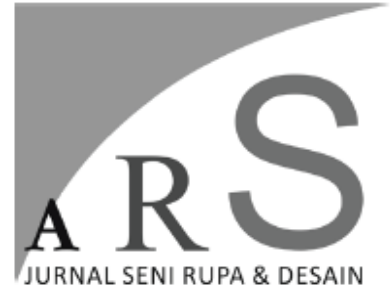

Volume 21 Nomor 1,

April 2018

\section{PERANCANGAN VIDEO PROFIL KHASANAH BATIK “ADI PURWO" KABUPATEN PURWOREJO}

\author{
Andini Retno Astrini \\ Program Studi Desain Komunikasi Visual, Jurusan Desain \\ Fakultas Seni Rupa,Institut Seni Indonesia Yogyakarta \\ E-mail: andineretno@gmail.com
}

\begin{abstract}
ABSTRAK
Kabupaten Purworejo, merupakan daerah yang potensial dengan hasil budaya lokal, salah satunya adalah industri kecil menengah batik. Dalam perkembangannya usaha batik lokal ini berkembang menjadi industri kreatif pembuatan dan pengembangan batik kahs Purworejo. Melalui usaha bersama di bawah badan usaha koperasi batik "AdiPurwo Raharjo",masyarakat komunitas sepakat memberi nama batik tersebut "AdiPurwo".Denganmotif khasnya yang terinspirasi dari bentuk makanan, buah, benda, hewan dan kesenian, objek tersebut menjadiciri khas dari potensi bumi Purworejo. Melalui metode pendekatan deskriptif dan analisis 5W $1 \mathrm{H}$ (What, Who, When, Why, Where, How), maka disusunlah konsep penciptaan pengenalan industri batik lokal Purworejo tersebut menggunakan media audio visual, sehinggapotensiyang dihasilkan dapat lebih dikenal dan menjadi identitas lokal KabupatenPurworejo.
\end{abstract}

Kata Kunci: batik lokal, motif khas Purworejo, video profil batik "Adi Purwo"

\begin{abstract}
Purworejo district, is a potential area with the result of the local culture is one of the small and medium industry batik. In its development of batik business is developed into a creative industry the creation and development of batik kahs Purworejo. Through a joint effort under the body of the batik cooperative business "Adi Purwo Raharjo", community community agreed to give the name of batik is "Adi Purwo". With the motif especially the inspired from the form of food, fruit, objects, animals and arts, the object become the characteristic of the potential of the earth Purworejo.Through the method of descriptive approach and analysis $5 \mathrm{~W} 1 \mathrm{H}$ (Subtitled, What, Who, When, Why, Where, How), then to composed the concept of the creation of the introduction of the batik industry Purworejo local use the audio visual media, so that the potential produced can be better known and become local identity in Purworejo district.
\end{abstract}

Keywords: local batik, special motif Purworejo, video batik profile "Adi Purwo" 


\section{Pendahuluan}

\section{Latar Belakang Masalah}

"Adi Purwo" merupakan batik kontemporer yang motifnya menggambarkan kondisi dan potensi yang ada di Purworejo. Potensi seni dan budaya ditampilkan dalam gambar penari nDolalak dan Bedug Purworejo, potensi pertanian dan perkebunan berupa manggis, durian dan empon-empon. Potensi lain misal kambing peranakan etawa.Potensi industri rakyat berupamakanan klanting, kue clorot, gula kelapa, geblek, kuelompong. Sedangkan pada jenis kain yang dipakai untuk pembatikan selendang menggunakan jenis Primisina dengan pewarna hitam, coklat, kuning, hijau dan merah. Perkembangan kerajinan batik "Adi Purwo" ini tergolong baru dan mulai pesat, karena kumpulan pengrajin yang semula hanya sebuah kelompok masyarakat yang memiliki kegiatan yang sama yaitu membatik, kini berkembang menjadi koperasi batik. Koperasi batik yang didirikan 24 Desember 2014 ini diberi nama Koperasi "ADI PURWO RAHARJO" yang beralamatkan di Jl. Sibak no.09 (Jl. Sarwo EdiWibowo).

Problem yang dihadapi batik "AdiPurwo"adalah promosi batik mereka yang masih terbatas pada media dan estetika. Sejumlah pengrajin batik tulis ini pun dibuat resah karena hadirnya batik printing yang marak dipasaran dengan perbedaan harga yang terpaut jauh dari batik tulisnya. Jika hal ini berlanjut bukan tidak mungkin batik tulis "Adi Purwo" akan mengalami pergeseran bahkan kemunduran karena kalah bersaing dengan batik printing tersebut. Namun bupati Purworejo sangat bijak untuk melestarikan batik khas "Adi Purwo" ini untuk mengharuskan pegawai pemkab memakai seragam batik "Adi Purwo", namunditengah usaha pelestarian tersebut realitas menunjukkan hasil produksi yang belum seimbang terhadap permintaan pasar dan produksinya sertakurangnya pengetahuan dalam mempromosikan batik tersebut ke dalam mediamedia yang inovatif. Biasanya masyarakat hanya mengandalkan mulut ke mulut atau sekedar menitipkan batik kepada toko-toko kain. Kendala saing terbesar mereka adalah batik luar daerah yang berkembang sangat pesat dengan beragam jenisnya yang lebih dikenal masyarakatluas. Oleh karena itu perancangan ini bertujuan untuk merancang video profil yang menarik untuk pengrajin-pengrajin batik "Adi Purwo" ,sebagai sarana untuk mempromosikan batik khas Purworejo yang nantinyadapat digunakan pada pameran industri atau investor agar lebihmeluas.

\section{Rumusan Masalah}

Bagaimana merancang video profile batik "Adi Purwo" berbasis multimedia sehingga mampu merefleksikan hasil budaya lokal adiluhung yang dapat merepresentasikan batik khas KabupatenPurworejo?

\section{Batasan Masalah}

Batasan masalah dalam proposal perancangan ini hanya akan merancang video profil berbasis multimedia dengan objek batik "Adi Purwo", sedangkan untuk proses distribusi media dan penempatannya diserahkan sepenuhnya kepada pihak Kabupaten Purworejo.

\section{Tujuan Perancangan}

1. Untuk menghasilkan konsep perancangan video profil promosi batik Purworejo.

2. Sebagai sarana informasi potensi batik tulis "Adi Purwo" Kabupaten Purworejo.

3. Perancanganvideo profil ini sebagai media untuk mengenalkan, mempromosikan dan melestarikan kain batik "AdiPurwo".

\section{Metode Perancangan}

Perancangan ini akan menggunakan metode analisis data deskriptif kualitatif. Metode analisis data deskriptif kualitatif dilakukan dengan cara pengumpulan data nara sumber, foto, dokumen, ataupun catatan yang diperoleh di lapangan pada saat penelitian. Purworejo yang diharapkan mampu memaksimalkan proses pembuatan video profil yang dilakukan olehperancang.

\section{Metode Pengumpulan Data \\ Studi Pustaka}


Perancang melakukan penelitian pustaka untuk mendapatkan referensii yang berkaitan dengan perancangan, karena data yang diperoleh dari studi pustaka adalah data yang diperoleh dari pihak kedua, sebagai acuanperancangan.

\section{Studi Lapangan}

a. Wawancara

Perancang melakukan wawancara dengan dinas kebudayaan kabupaten Purworejo, ketua pengurus koperasi "ADIPURWO RAHARJO” , dan pengrajin lokal. Wawancara yang dilakukan merupakan wawancara tidak terstruktur, yaitu wawancara yang ringan dan tidak terlalu formal. Metode wawancara ini sendiri diyakini dapat memberikan data yang akurat karena bersumber langsung dari pihak yang mengetahui jelas tentang batikPurworejo.

b. Observasi

Observasi dilakukan dengan mengamati langsung di lapangan terhadap objek.

c. Dokumentasi

Dokumentasi dilakukan dengan mengambil data berupafoto-fotodan pengambilan data berupa video shoot berkaitan dengan batik Purworejo.

\section{Metode Analisis Data}

Dalam analisis permasalahan untuk perancangan video profil ini menggunakan $5 \mathrm{~W}+1 \mathrm{H}$ (What, Where, When, Why, Who dan How) karena dinilai lebih tepatuntukmemecahkan permasalahan perancangan tersebut.

\section{DataPrimer}

Data primer atau data langsung yang dilakukan oleh perancang merupakan data yang didapat langsung dari pengamatan dan wawancara kepada narasumber, dalam perancangan ini ruang lingkup hanya pada pengrajin batik atau produsen "Adi Purwo", sehingga perancangan dapat sesuai dengan tujuan.

\section{Data Sekunder}

Data sekunder yang diperlukan perancang merupakan data pendukung yang didapat dari hasil studi literature yang akan perancang gunakan sebagai landasan dalam perancangan video profil khasanahbatik.

\section{Hasil danPembahasan}

Berdasarkan dari hasil analisis a wal yang dilakukan maka didapatkan sebuah acuan perancangan media informasi batik Purworejo berupa video profil sebagai media utama, dengan tema budaya lokal sebagai gambaran dari salah satu pelestarian budaya yaitu kain tradisional yang dimiliki Kabupaten Purworejo.

\section{Konsep Perancangan}

Konsep perancangan video profil khasanah batik Purworejo dirancang dari praproduksi yaitu tahap awal atau persiapan video profil dengan memproses materi outline dari objek yang berisi shooting object, durasi, target audience, tempat/ setting, budged, dan lainnya, sampai ke tahap produksi yang mana tahap pelaksanaan shooting video profiledilakukan.

\section{Identifikasi Dan Analisis Data \\ Data Produk}

1. Sejarah Batik "Adi Purwo" Purworejo

Kabupaten Purworejo merupakan salah satu kabupaten yang telah lama memproduksi kain batik tradisional maupun batik kontemporer. Berawal dari batik tradisional atau batik klasik Bagelenan di daerah pesisir, batik Purworejo berkembang dengan memadukan corak batik klasik dengan corak ragam hias dari potensi yang ada di Purworejo. Sebagai kabupaten yang berdekatan dengan kerajaan Mataram kuno, Purworejo hingga saat ini masih meneruskan adat dan budaya yang diwariskan oleh kerajaan Mataram kuno mulai abad XI yang diantaranya adalah budayamembatik.

Perkembangan batik tulis di kabupatenPurworejomerupakan budaya turun menurun dari sesepuh atau orang yang terdahulu, namun seiring perkembangannya budaya membatik tersebut seakan mati suri hingga dikembangkan kembali pada ta hun 2006 dengan dibuatnya kelompok pengrajin 
batik Laras Ndriyo yang terdiri dari desa Sumber Agung yang berjumlah kurang lebih ada sepuluh orang dan di desa lainnya yaitu desa Grabag, Rejo Sari dan Kudu Kulon. Sentra batik yang terdapat di kabupaten Purworejo tersebut di beberapa kecamatan yaitu kecamatan Banyu Urip, Bruno, Purworejo dan Bagelen. Kondisi dan potensi yang ada di kabupaten Purworejo sangat beragam, sehingga diangkat menjadi ragam corak batik khas "AdiPurwo" Purworejo. Potensi seni dan budaya ditampilkan dalam ragam corak penari dolalak dan bedug Purworejo yang terbesar di Indonesia, potensi pertanian dan perkebunan berupa mangis, durian dan empon-empon, potensi peternakan berupa kambing peranakan ettawa, potensi industri rakyat berupa makanan klanting, kue clorot dan gula kelapa. Potensi-potensi tersebut yang dijadikan inspirasi dalam menciptakan motif batik khas "Adi Purwo" Purworejo yang merupakan batik kontemporer.

Terdapat perbedaan antara batik khas "Adi Purwo" Purworejo dengan batik tradisional atau batik klasik, yang membedakan adalah ragam corak atau ragam hiasnya, batik tradisional dikenal denganmotif melati secontong, lung kenongo, nam kepang, laras ndriyo, pisang bali, limaran, lung semongko, buntal kampuh, menyan kobar, sidoluhur, sidomukti, lelermengeng, parang, kawung dan masih banyak motif tradisional lainnya. Sedangkan pada batik khas "Adi Purwo" Purworejo motifnya berupa potensipotensi yang ada di Purworejo dengan beragam potensinya.

Desainer motif "Adi Purwo", Hartanti Hartomo, mengemukakan bahwa ide tersebut diperoleh saat dirinya mengikuti lomba Karya Batik Nusantara tingkat nasional yang diselenggarakan di Balai Batik Yogyakarta. Saat itu dirinya mengangkat tema "Tradisi dan Modernitas Menuju Identitas", ia menampilkan batik bermotif potensi
Purworejo. Saat itu ia masih memberi nama dengan "Pesona Purworejo", ternyata ragam corak dengan potensi yang ada di Purworejo mempunyai daya tarik tersendiri bagi dewan juri dan hal ini terbukti mampu membawa ragam corak tersebut masuk ke dalam 20 besar dari dua ratus peserta.

2. Filosofi Batik "Adi Purwo"Purworejo

Dikemukakan bahwa batik khas "Adi Purwo" dengan motif yang diangkat dari potensi-potensi yang ada di Purworejo merupakan jenis batik kontenporer, bukan tanpa alasan potensi-potensi tersebut menjadiragam hias corak batik "Adi Purwo" melainkan karena adanya filosofi pada setiap potensi yang diangkat yang mewakilkan kabupaten Purworejo itu sendiri. Pemberianragam hias potensi daerah memiliki makna tersendiri, gula kelapa merupakan industri rakyat di beberapa wilayah kabupaten Purworejo, produksinya mencapai 2-3 kwintal per hari, pemasarannya hingga kota besar seperti Semarang, Yogyakarta danSolo.

Padi bermakna bahwa Purworejo merupakan lumbung padi di eks Karesidenan Kedu, area penanaman yang luas ditunjang sistem irigasi teknis dan non teknis, menggambarkan kemakmuran. Buah manggis dan durian merupakan produk unggulan dari bidang pertanian dan perkebunan di pegunungan, sedangkan empon-empon yang berupa kencur, jahe, kunyit, kapulaga dan temulawak merupakan bahan pembuat jamu yang menjadi potensi yang dimiliki masyarakat perbukitan. Kambing Ettawa yang merupakan potensi besar yang dihasilkan dari peternakan yang ada di Purworejo yang juga menjadi ikon utama dari kabupaten Purworejo. Klanting dan kue clorot merupakan makanan yang dihasilkan dari industri rakyat yang menjadi makanan khas kabupaten Purworejodan biasanya digunakan sebagai oleh-oleh khas kabupatenPurworejo. 
Sedangkan ragam hias yang biasanya digunakan pada bagian tumpal yaitu penari nDolalak yang merupakan potensi kesenian yang dimiliki kabupaten Purworejo yang tumbuh sebagai hasil akulturasi budaya barat dan timur, dan bedug Pendowo yang merupakan bedug terbesar yang ada di Indonesia yang terletak di kabupaten Purworejo ini sebagai makna dari potensi budaya yang sudah dikenal. Ada pula bunga cengkeh yang merupakan aksesoris yang terdapat pada kostum penari nDolalak. Dari semua ragam hias motif yang ada menggunakan latar dengan hiasan pasiran yang bermakna bahwa Kabupaten Purworejo memiliki potensi sumber daya alam yaitu pasirbesi.

3. Motif Batik "Adi Purwo" Purworejo

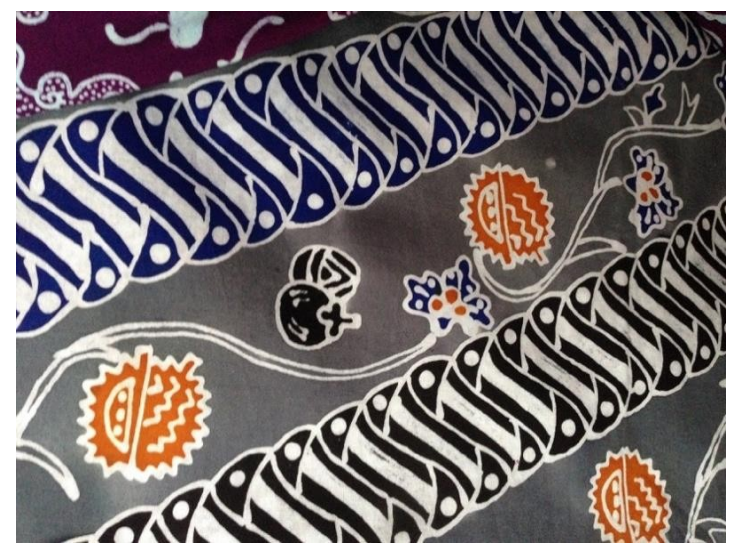

Gambar 1. Motif Durian dan Manggis (Sumber: Dokumentasi Andini Retno Astrini)

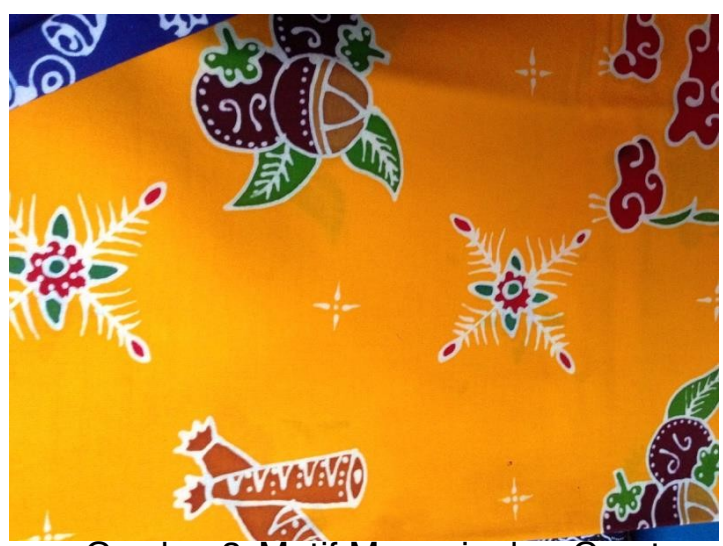

Gambar 2. Motif Manggis dan Corot

(Sumber:Dokumentasi Andini Retno Astrini)

Gambar 3. Motif Tari nDolalak

(Sumber: Dokumentasi Andini RetnoAstrini)

Gambar 4. Motif Kambing Etawa

(Sumber: Dokumentasi Andini Retno Astrini)

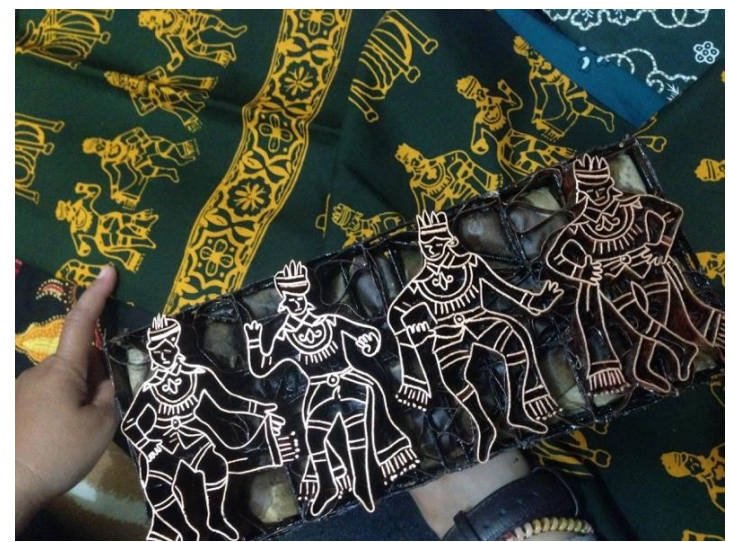

\section{Landasan Teori}

1. Batik

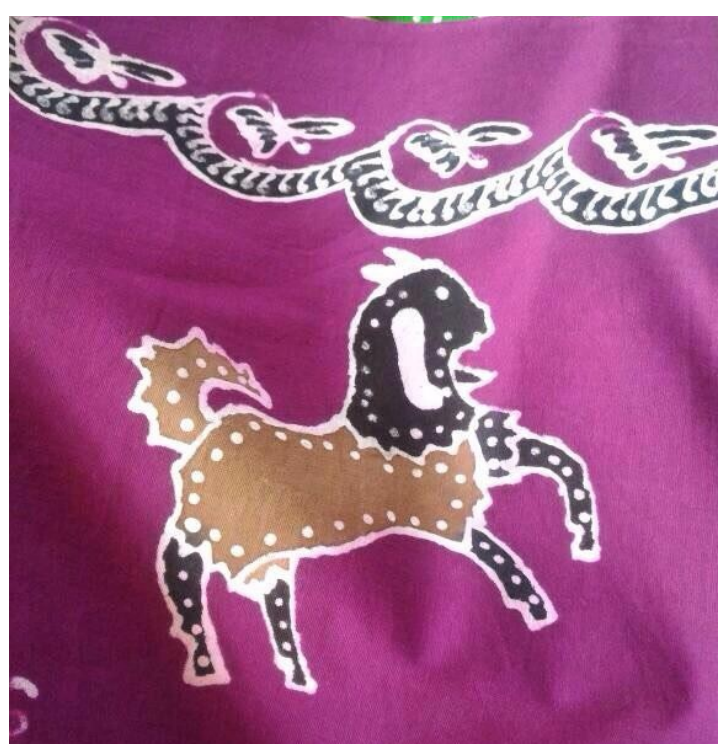

Adalah salah satu cara pembuatan bahan pakaian. Selain itu,batik bias mengacu pada dua hal. Pertama, adalah teknik pewarnaan kain dengan menggunakan malam untuk mencegah pewarnaan sebagian dari kain. Dalam literature internasional, teknik ini dikenal sebagai wax-resist dyeing. Kedua, adalah kain atau busana yang dibuat denganteknik tersebut, termasuk penggunaan motif-motif tertentu yang memiliki kekhasan. (Prasetyo, 2010:1) Batik Indonesia, sebagai keseluruhan teknik, teknologi ,serta pengembangan motif dan budaya yang terkait, oleh UNESCO telah ditetapkan sebagai Warisan Kemanusiaan untuk Budaya Lisan dan Non Bendawi (Masterpieces of The Oral and Inteligence Heritage of Humanity) sejak 2 Oktober2009.

Berdasarkan etimologi dan 
terminologinya, batikmerupakan rangkaian kata mbat dan tik. Mbat dalam Bahasa Jawa diartikan sebagai ngembat atau melempar berkali-kali, sedangkan tik berasal dari kata titik. Jadi, membatik berarti melempar titiktitik berkali-kali pada kain. Sehingga akhirnya bentuk-bentuk titik tersebut berhimpitan menjadi bentuk garis. Selain itu, batik juga berasal dari kata mbat yang merupakan kependekan dari kata membuat, sedangkan tik adalah titik. (Musman \& Arini, 2011:1) Batik merupakan bahan kain yang sangat erat dengan nilai budaya masyarakat, sehingga batik tidak saja sebagai hasil produksi semata, tetapi juga merupakan hasil budaya dari suatumasyarakat.

2. Video Profil

$$
\begin{aligned}
& \text { Video adalah teknologi } \\
& \text { menangkap, merekam, memproses, } \\
& \text { mentransmisikan dan menata ulang gambar } \\
& \text { bergerak. Biasanya menggunakan film } \\
& \text { seluloid, sinyal elektronik,atau media } \\
& \text { digital. Video juga bias dikatakan sebagai } \\
& \text { gabungan gambar-gambar mati yang dibaca } \\
& \text { berurutan dalam suatu waktu dengan } \\
& \text { kecepatan tertentu. Gambar-gambar yang } \\
& \text { digabung dinamakan frame dan } \\
& \text { kecepatan gambar disebutframe rate. } \\
& \text { Istilah itu berasal dari } \\
& \text { fotografi di mana menggambarkan } \\
& \text { mekanis "pintu" antara lensa kamera dan } \\
& \text { film. Ketika sebuah foto diambil, pintu } \\
& \text { terbuka sesaat dan film terkena cahay } \\
& \text { ayang masuk. Kecepatan membuka dan } \\
& \text { menutup dapat divariasikan semakin cepat } \\
& \text { kecepatan, semakin pendek periode waktu } \\
& \text { terbuka, dan semakin sedikit cahaya jatuh } \\
& \text { pada film. Kecepatan diukur dalam } \\
& \text { sepersekian detik. Sebuah kecepatan } 1 / 60 \\
& \text { detik berarti bahwa tombol terbuka untuk } \\
& \text { seperenampuluh detik. Sebuah } \\
& \text { kecepatan } 1 / 500 \text { adalah lebih cepat, dan } \\
& \text { 1/10000 memang sangat cepat. } \\
& \text { oleh para ahli, video profil dapat diartikan } \\
& \text { sebagai sebuah rekaman yang ditayangkan } \\
& \text { di TV atau media audio visual lainnya } \\
& \text { yang merepresentasikan sebuah identitas }
\end{aligned}
$$

dan pencitraan yang baik terhadap suatu perusahaan. Video profil adalah juga merupakan sebuah media yang efektif untuk dijadikan sebuah alat dalam mempropagandakan sebuah perusahaan, produk hingga sebagaimedia dalam mengenalkan suatu potensi daerah. Metode ini mempunyai dua metode komunikasi, yaitu audio dan visual yang tentunya membuat penyampaian propaganda ataupun promosi semakin efektif. Selain dikemas dalam format linier (dioperasikan melalui media player seperti VCD atau DVD) yang dapat diproduksi melalui $\mathrm{CD}$ interaktif dan dioperasikan melalui computer (Produksi Indonesia:2007).

$$
\text { Menurut Wawan Kuswandi }
$$

(Kuswandi, 2011:47), video profil merupakan sebuah bentuk informasi yang di dalamnya berisi tentang riwayat seseorang atau suatu perusahaan yang telah mencapai sebuah kesuksesan di dalam hal produksi ataupun hasil karya yang dihasilkan mempunyai sebuah keunikan dan dapat diterima oleh masyarakat padaumumnya.Menurut Fred Wibowo (2012: 34-36), video profil perusahaan merupakan video yang dibuat atau diproduksi untuk mengenalkan suatu perusahaan dan sebagai salah satu sarana untuk mempresentasikan sebuah perusahaan atau kelompok tertentu. Dari beberapa penjelasan di atas dapat ditarik kesimpulan bahwa video profil adalah sebuah media audio visual yang berisi informasi tentang riwayat seseorang atau sebuah perusahaan untuk sarana mempromosikan hasil produksi dan keunggulan yang dimiliki kepada masyarakat umum dalam bentukvideo.

\section{Komunikasi Visual}

Komunikasi visual adalah sebuah rangkaian proses penyampaian informasi atau

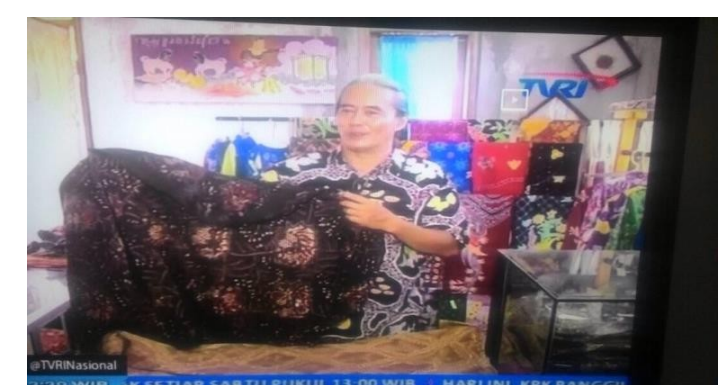


pesan kepada pihak lain. Komunikasi tersebut menggunakan media yang hanya terbaca secara visual oleh indera penglihatan atau mata. Visual sendiri berasal dari Bahasa Latin "videre" yang berarti melihat. Sedangkan komunikasi berasaldari Bahasa Inggris, yaitu "communication" yang diambil dari Bahasa latin "communio" yang berarti kebersamaan (dalam Bahasa Inggris: common). Kemudian komunikasi dianggap sebagai proses menciptakan suatu kesamaan (commonness) atau suatu kesatuan pemikiran antara pengirim (komunikator) dan penerima.(komunikan) (Anggraini, 2014:13)

\section{Kajian Pustaka}

Sebagai referensi kajian pustaka video profil adalah channel pada program siaran TVRI Nasional Program : Kain Nusantara, yang ditayangkan pada tanggal : 31 Mei 2017, pukul 14.00WIB.

Program Kain Nusantara disini membahas konten tentang batik khas daerah Purworejo yang dikenal dengan batik Adi Purwo, dengan penyajian video berupa berita informasi yang menggunakan plot major dengan jenis plot sirkuler (plot yang dimulai dari cerita A dan kembali lagi ke titik A). Dalam video ini plot major adalah si kain batik Adi Purwo dan plotnya diawali dengan lembaran macammacam kain batik Adi Purwo lalu menceritakan isi dan kembali lagi ke cerita awal. Video ini merupakan video berita yang tujuannya memberikan berita atau informasi tentang adanya kain tradisional khas Purworejo dengan beberapa narasumbernya seperti Wakil Bupati sebagai orang nomor dua di Purworejo, pengamat batik, seniman batik sampai pengrajin batiknya yang tujuannya memaparkan tentang berita adanya kain batik Adi Purwo yang jarang diketahui orang.

Gambar 5. Resensi tayang batik Nusantara. (Sumber: Capture Dok. TVRI, diakses 23 Juni 2017, pukul; 21.13 WIB)

Gambar 6. Resensi tayang batik Nusantara. (Sumber: Capture Dok. TVRI, diakses 23 Juni
2017, pukul; 21.13 WIB)

Sedangkan video profile yang dibuat oleh penulis merupakan video dengan jenis feature semacam video dokumenter namun dikemas lebih sederhana dan tidak mendetail seperti dokumenter. Narasumber yang digunakan oleh penulis juga tidak berbeda jauh seperti Jazid Bastomi selaku seniman batikdan perancang busana serta Retno Andriastuti selaku pengrajin batik, namun disini penulis lebih menggunakan pencetus awal diangkatnya kembali batik Purworejo yaitu Bapak H.Kelik Sumrahadi, S.Sos. MM. selaku mantan Bupati Purworejo periode 2005- 2008 sebagai penguat data pada video yang dibuat oleh penulis. Tujuan dari video ini pun sama ingin mengenalkan batik khas Purworejo agar lebih dikenal luas, namun penulis mengemasnya dengan plotline major yaitu batik sebagaitokoh utamanya dan menggunakan plot linier yaitu penulis menceritakan perjalanan batiktersebutsecaragarisbesardengan titik $\mathrm{A}$ dan berakhir di titik $\mathrm{D}$ dengan melewati titik $\mathrm{B}$ dan titik $\mathrm{C}$ secara berurutan, dan penulis juga tidak menggunakan pembawa acara hanya menggunakan voice over sebagai penjelas video tersebut agar lebih sederhana dan mudah dicerna oleh audience karna nantinya penulis mengharapkan video ini digunakan di videotron maupun mediasosial sebagai sarana pengrajin untuk memasarkanhasil batiknya dan mengenalkan ke masyarakatluas.

\section{Analisa Data}

\section{What}

Apa permasalahan yang dihadapi kabupaten Purworejo dalam mempromosikan batik lokalnya? Dengan perkembangan tekhnologi yang canggih diberbagai aspek dan terbatasnya kemampuan serta minimnya

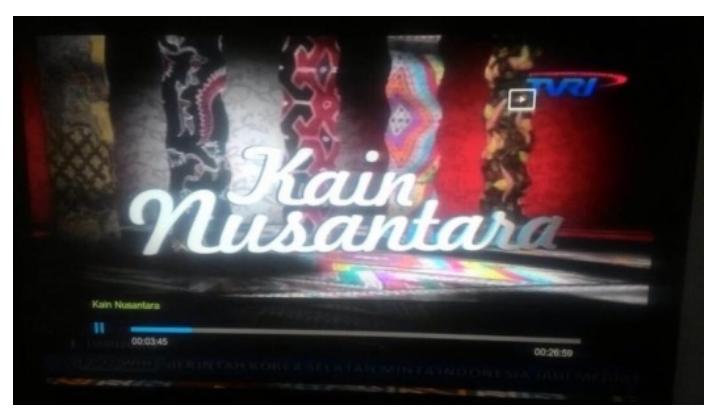


pengetahuan yang tidak merata, pengrajin batikdi kabupaten Purworejo ini hanya mempromosikan batiknya di toko beberapa daerah, dari mulut kemulut, atau saat ada pameran kesenian atau pameran daerah. Dengan ini mereka membutuhkan video profil sebagai cara untuk mengikuti perkembangan tekhnologi yang ada untuk mempromosikan produk mereka yang nantinya dapat digunakan diberbagai media sosial seperti Facebook, Instagram, Youtubedan media sosial lainnya yang mampu dilihat lebih banyak orang.

2. Where

Dimana saja media informasi video profil khasanah batik Purworejo akan digunakan? Di media sosial seperti Facebook, Instagram, Youtube atau media lainnya yang sedang digemari dan di videotron. Dengan menggunakan media social yang memiliki bentuk pertemanan yang berantai sebagai media penyebaran video profil ini memungkinkan banyak orang yang melihat dan saling berbagi video ini, sedangkan di videotron orang akan secara tidak sengaja melihat dengan sering ketika mereka melintas di jalan yang disediakan videotrontersebut.

3. When

Kapan media informasi video profil digunakan? Media informasi video profil ini akan mulai digunakan setelah lebaran yaitu 27 Juni 2017.

4. Why

Mengapa kabupaten Purworejo membutuhkan media informasi ini? Karena mereka harus mengikuti perkembangan tekhnologi yang ada agar lebih dikenal dan diminati banyak kalangan, maka video ini akan mulai dikenalkan ke target audience dengan cara mengunduh videoprofil ini ke dalam aplikasi media social youtube lalu akan di teruskan menggunakan Facebook, Instagram, Line, Twitter dan Path.

5. Who

Siapa yang akan menjadi sasaran khalayak pada video profil ini? Masyarakat dengan kisaran umur 9 tahun sampai 65 tahun, karena umur 9 tahun adalah umur yang tepat untuk mengenal dan mulai dapat perduli dengan sekitarnya dan umur 65 tahun adalah umur yang tepat sebagai orang yang akan menceritakantentang batik tradisional ini kepada penerusnya.

6. How

Bagaimana menginformasikan kepada masyarakat luas akan eksistensi dan kualitas dari batik Purworejo?Dengan dibuatnya video profil tentang batik khas "Adi Purwo" kabupatenPurworejo ini diharapkan dapat memberikan informasi kepada target audience akan eksistensi dan kualitas yang dimiliki batik kontenporer kabupaten Purworejo dengan cara mengunduh video profil tersebut ke mediasosial.

\section{Kesimpulan Analisis}

1. AspekProduk

Dalam aspek produk, Batik "Adi Purwo" menggunakan material yang berkualitas serta pewarna yang cenderung alami seperti sogan dan pewarna alami lainnya dan jenis bahan yang digunakan untuk membatik dengan karakter motif yang unik dari potensi alam maupun industri yang dihadirkan, membuat produk ini unggul dan berkualitas.

2. Aspek Pasar /Konsumen

Jika dilihat dari material yang digunakan dan harga yang bervariasi dengan berbagai jenis yang ditawarkan, pasar dapat menjangkau berbagai macam kalangan konsumen dari yang bawah seperti konsumen yang biasanya dari pedesaan maupun konsumen menengah keatas yang biasanya dari perkotaan bahkan mancanegara batik ini mampu menyediakan kebutuhan pasar batik dengan berbagaiaspek kebutuhan konsumen untuk oleh-oleh maupun sebagai kenang-kenangan.

\section{Tujuan Komunikasi}

Dalam perancangan Video Profil ada tujuan komunikasi yang digunakan dalam pembuatannya, hal ini ditujukan untuk menyampaikan apa saja yang akan 
diinformasikan kepada audience agar tepat sasaran sehingga audience mengerti apa maksud dan tujuan yang ada di dalam video tersebut. Mulai dari proses pra produksi, produksi, hingga pasca produksi. Dalam video ini akan dimasukkan pembahasan mengenai sejarah singkat(masa lalu) dan harapan-harapan(masa depan) pihak terkait terhadap batik "AdiPurwo". Melalui video ini, diharapkan audiens mengenal batik "Adi Purwo" sebagai salah satu batik khas kabupaten Purworejo sehingga memunculkan keinginan untuk mengenal lebih dalam kemudian mengenalkannya kepada khalayak lebih luas di kemudianhari.

\section{Konsep Kreatif}

Target Audience perancangan ini adalah masyarakat luas lokal maupun mancanegara yang tertarik pada kain tradisional. Adapun pengambilan angle secara konsep menampilkan gambar yang menarik dan movement yang baik serta sentuhan estetika diharapkan mampu memberi daya tarik tersendiri pada perancangan video profil ini.

1. TujuanKreatif

Tujuan kreatif perancangan video ini adalah mengemas informasi mengenai batik "AdiPurworejo" ke dalam karya audio visual secara informatif, runtut, dan jelas dengan tidak lupa memasukkanunsur budaya Purworejo. Selain itu, video ini dikemas menarik dengan memperkaya visual agar audiens tertarik lebih dalam lagi untuk mengenal dan kemudian mengenalkan batik"AdiPurwo" Purworejo ke khalayak dengan jangkauan yang lebih luas.

2. StrategiKreatif

Strategi kreatif dilakukan dalam upaya mencapai tujuan kreatif produksi video ini. Tak jarang, strategi kreatif dianggap sebagai hasil terjemahan dari bebagai informasi mengenai pesan yang akan disampaikan ke dalam suatu posisi tertentu di dalam komunikasi sesuai dengan tujuan perancangan. Strategi kreatif pada perancangan video ini berupa penyajian gambaran cerita yang runtut dari opening sampai akhir mengacup ada satu topik permasalahan yang fokus, yaitu "batik "Adi Purwo"adalah batik khas Purworejo".Video ini ditunjang dengan narasi (voice over) yang menyertai video dari awal sampai akhir. Bahasa Indonesia sebagai bahasa yang digunakan dalam penyampaian narasi mengingat bahasa Indonesia merupakan bahasa persatuan yang dipahami sebagian besar warga negara Indonesia. Narasi akan diiringi dengan musik instrumental dalam membangun mood, dengan isi dan gambaran seperti:

\section{a. What to say}

Isi pesan dari video profil ini adalah bagaimana kita perduli dan dapat melestarikan salah satu warisan budaya jangan sampai hilang, dengan dibuatnya alur ceritayang santai dan berurutan serta adanya penjelasan dari cara pembuatan batik tersebut diharapkan audience mengerti akan uniknya dan indahnya proses pembuatan batik itu sendiri sampai menjadi kain yang indah. Seperti yang dikatakan oleh salah satu narasumberdi dalam video tersebut yaitu,"hidup akan lebih indah dengan seni". Membatik adalah salah satu seni dan harus dilestarikan, jika seni itu ada pada hidup kita maka bangsa ini tidak akan kehilangan warisan budayanya.

\section{b. How to say}

Bentuk pesan pada video ini tersirat dari kata-kata yang diungkapkan oleh narasumber dan proses pembuatan batik itu sendiri, karena dengan melihat langsung proses pembuatan batiknya dan alam yang dimiliki negeriini, audience akan kagum dengan apa yang dimiliki daerahnya dan berusaha untuk perduli dan mulai melestarikan serta mengenalkannya lebih luas lagi.

\section{Konsep Media}

Video ini berisi mengenai informasi tahapan-tahapan produksi batik "Adi Purwo" 
mulai dari proses pra produksi, produksi, hingga pasca produksi. Informasi tersebut akan disampaikan dalam bentuk narasi (voice over) yang menyertai video dari awal sampai akhir. Narasi disampaikan dalam bahasa Indonesia karena bahasa Indonesia merupakan bahasa persatuan yang dapat dipahami oleh sebagian besar wargaIndonesia.

Video ini menggunakan pendekatan video dokumentasi dengan plot/alur cerita yang runtut dan jelas. Tidak lupa dalam perancangan video ini kontinuitas menjadi hal yang sangat penting agar cerita menjadi satu kesatuan yang utuh dan dapat dengan mudah ditangkap maksud dan pesannya oleh audiens. Kontinuitas dapat berupa keruntutan jalan cerita, sudut pengambilan gambar dan frame size yang bervariatif dengan tetap focus pada objek yang didokumentasikan mengacu pada jalan ceritayang sudah ditentukan sebelumnya serta pencahayaan yang konsisten.

\section{Tujuan Media (VideoProfile)}

Selain tujuan komunikasi, adanya tujuan media yang digunakan dalam perancangan video profil sangat diperlukan dalam proses pembuatannya untuk meminimalisir salah sasaran target audience. Agar tepat sasaran dibutuhkan analisis yang tepat agar media yang diterapkan mencapai target sasarannya. Perancangan video profil ini bertujuan untuk menjangkau target audiens, yaitu semua kalangan yang berusia 9 tahun sampai 50 tahun dengan segala jenis kelamin. Penggunaan video profil sebagai media penyampai informasi karena video sebagai salah satu produk audio visual terasa lebih dekat dengan audiens karena apa yang ditampilkan secara visual realis atau sama dengan kondisi lapangan. Selain itu, video juga memiliki kelebihan dapat mengkomunikasikan suatu pesan atau informasi dengan dua bahasa, yaitu bahasa gambar dan bahasa suara, serta dapat diulang-ulang, praktis, mudah digandakan, danbiaya produksinya terbilang lebih murah daripada produksi film seluloid.

\section{StrategiMedia}

Strategi media merupakan suatu metodologi yang diterapkan untuk mencapai tujuan media. Oleh karena itu, strategi media dapat dikatakan sebagai usaha mencapai khalayak yang disasar sehingga tepat sasaran berdasarkan apa yang telah ditentukansebelumnya.

\section{Plot Cerita /Alur}

Sebuah cerita pasti memiliki plot atau alur pada jalan ceritanya agar audience dapat memahami cerita yang dibuat, begitu juga pada video profil ini yang menggunakan alur cerita maju atau plot linier yang menceritakan secara berurutan dari titik A melalui titik B dan titik C serta berakhir di titik D , dengan batik Adi Purwo sebagai plot line majornya.

\section{Sinopsis}

Indonesia merupakan negara yang kaya akan budaya, salah satunya budaya membatik. Hampir disetiap daerah yang ada di Indonesia memiliki kain batik khasnya, termasuk Purworejo.Purworejomerupakan salah satu kabupaten yang ada di Jawa Tengah ini juga memiliki kain batik khasnya yaitu Batik "Adi Purwo" Purworejo. Batik "Adi Purwo" ini merupakan batik kombinasi dari batik klasik Purworejo dengan motif baru yang terinspirasi dari potensi-potensi yang ada di Purworejo seperti kambing etawa, buah manggis, buah durian, celorot, geblek sampai dengan penari dolalaknya. Batik "Adi Purwo" telah ada sejak tahun 2006 dengan pengembangan motif kombinasiny yang juga disebut batik kontenporer. Meskipun batik ini jarang diketahui orang banyak, batik "Adi Purwo" tetapmenjaga eksistensinya dengan cara hadirdiberbagaipameran batik maupun pameran industri kecil yang di adakan di kota Purworejo. Sangat disayangkan batik ini kurang berkembang dari segi promosinya, keterbatasan pengrajin batik dalam memasarkan hasil karyanya membuat batik ini hanya dikenal oleh kalangan tertentu saja. Karenaitu video profil ini hadir untuk membantu para pengrajin dalam memasarkan produknya dan mengenalkan batik "AdiPurwo" Purworejo lebih luas lagi melalui teknologi media maupun media social yang sedang 
popular.

\section{Kesimpulan}

Sebagai produk budaya lokal, batik "Adi Purwo" yang pada awalnya merupakan usaha sekelompok masyarakat kecil di Kabupaten Purworejo, pada akhirnya mampu menggerakkan ekonomi masyarakat setempat yang berdampak dapat memajukan ekonomi kreatif dan sumber daya manusiasetempat.Kegiatan ini mampu menunjukkan lokalitas, warna, ciri dan bentuk baru pengembangan batik di wilayah kedu khususnya di kabupaten purworejo. Tidak hanya menghasilkan pola dan sajian visual yang khas, namun lebih dari itu hasil varian batiktulis tangan "Adi Purwo" selain menjadi jati diri lokalitas wilayah, hadir disaat yang tepat yaitu mewarnai budaya jaman, budaya visualkontemporer.

Dengan target anak muda dari kelas menengah ke atas, ciri motif, warna batikini dianggap dapat mengikuti selera jaman. Namun semua usaha tersebut tidak akan berhasil dan menjadi komoditas yang kuat apabila tidak ditunjang oleh kegiatan promosi. Untuk itu melalui Perancangan tugas akhir karya video profil ini dapat memacu usaha perluasan kegiatan batik khas Kabupaten Purworejo dengan brand batik "AdiPurwo". Selama penyusunan video profil ini pada awalnya cukup mendapat kesulitan mengingat kegiatan membatik, untuk menghasilkan sebuah karya memerlukan waktu cukup lama, setidaknya 3 (tiga) bulan guna mendapatkan hasil kain batik yang bermutu bagus, namun dengan segala kesabaran,kesulitan ini dapat diatasi dengan berusaha doa dan ketekunan mendokumentasikan setiap kegiatandan aktifitas membatik tersebut dengan menginap di tempat perajin batik di beberapa lokasi, desa dan wilayah kecamatan perajin batik di bawah wadah batik "AdiPurwo".

\section{Saran}

Di masa mendatang, bagi usaha industri kerajinan sejenis, guna mendapatkan peluang pasar yang lebih luas, maka kegiatan tersebut perlu mendapatkan dukungan promosi yang memadai. Sebuah usaha yang bagus namun apabila tidak didukung oleh kegiatan komunikasi, maka niscaya nilai keberhasilan dapat dikatakan kurang maksimal. Batik Kabupaten Purworejo sebagai batik unggulan dan usaha baru dengan visualisasinya yang unik, telah mencoba menggali potensi daerah, dan ternyata mampu membuat corak dan warnanya yang khas serta menjadi pendorong berputarnya roda ekonomi kreatif di suatu wilayah. Perlunya mengajak kerjasama dengan mitra kerja dalam upaya menumbuh kembangkan dan meningkatkan kegiatan ini, maka salah satunya adalah dengan menciptakan serangkaian bentuk promosi yang memadai. Untuk itu melalui perancangan video profil ini kiranya dapat dijadikancontoh bagaimana sebuah kegiatan industri memerlukan upaya itu.

\section{Daftar Pustaka}

Anggraini. (2014). Perbedaan Dan Persamaan Kualitatif Dan Kuantitatif. Jakarta: Guna Dharma Press.

Kuswandi, W. (2011). Komunikasi Massa Sebuah Analisis Media Televisi. Jakarta: Rieneka Cipta.

Musman, A., \& Arini, A. B. (2011). Batik: Warisan Adiluhung Nusantara,. Yogyakarta: Andi Offset.

Prasetyo, A. (2010). Batik: Karya Agung Warisan Budaya Dunia. Yogyakarta: Pura Pustaka.

Wibowo, F. (2012). Teknik Produksi Program Televisi. Yogyakarta: Pinus. 